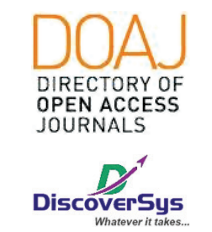

Published by DiscoverSys

\section{Analisis korelasi kadar serum prokalsitonin dengan jumlah leukosit pada penderita dengan kecurigaan sepsis di RSUP Sanglah, Bali, Indonesia}

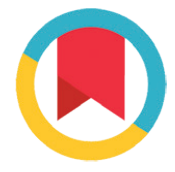

CrossMark

\author{
Bagus Dwiki Arya Dharma, ${ }^{1 *}$ Ni Kadek Mulyantari, ${ }^{2}$ I Putu Yuda Prabawa ${ }^{2}$
}

\section{ABSTRACT}

Background: Sepsis is a systemic inflammatory response to infection, where the pathogen or toxin is released into the blood circulation, causing activation of the inflammatory process. Laboratory tests are used to detect inflammatory processes, one of which is procalcitonin. This study aims to determine the correlation between procalcitonin (PCT) serum levels by the leukocytes counts on suspected sepsis patients at Sanglah Hospital in Denpasar.

Methods: An analytic observational study with the cross-sectional design was conducted among 21 samples by consecutive sampling technique. The population in this study were sepsis patients who were treated at Sanglah Hospital Denpasar during February-June 2016 period. Data were analyzed using SPSS version 17 for Windows.

Results: Most of respondents were $>35$ years old $(85.7 \%)$, Body Mass Index (BMI) $>20 \mathrm{~kg} / \mathrm{m} 2$ (76.2\%), leucocyte counts $<10.000 / \mu \mathrm{L}$ (42.9\%), and PCT levels $\leq 0.5 \mathrm{ng} / \mathrm{mL}$ (61.9\%). There is no significant correlation between white blood cells (WBC) and PCT by Spearman Correlation test ( $p=0.061 ; r=0,641)$.

Conclusion: The recent findings suggest that there was no significant correlation between PCT serum levels with the leucocytes counts among patients with sepsis.

Keywords: procalcitonin, leukocyte count, sepsis

Cite This Article: Dharma, B.D.A., Mulyantari, N.K., Prabawa, I.P.Y. 2020. Analisis korelasi kadar serum prokalsitonin dengan jumlah leukosit pada penderita dengan kecurigaan sepsis di RSUP Sanglah, Bali, Indonesia. Intisari Sains Medis 11(1): 179-182. D0I: 10.15562/ism.v11i1.525

\title{
ABSTRAK
}

Latar Belakang: Sepsis merupakan suatu respon inflamasi sistemik terhadap infeksi, dimana patogen atau toksin dilepaskan ke dalam sirkulasi darah sehingga terjadi aktivasi proses inflamasi. Tes laboratorium yang digunakan untuk mengetahui adanya proses inflamasi salah satunya adalah prokalsitonin (PCT). Penelitian ini bertujuan untuk mengetahui korelasi antara kadar serum prokalsitonin dengan jumlah leukosit pada penderita dengan kecurigaan sepsis di RSUP Sanglah Denpasar.

Metode: Penelitian observasional analitik dengan desain tong lintang dilakukan terhadap 21 sampel dengan teknik konsekutif. Populasi dalam penelitian ini adalah pasien sepsis yang dirawat di Rumah Sakit
Sanglah Denpasar selama periode Februari-Juni 2016. Data dianalisis menggunakan SPSS versi 17 untuk Windows.

Hasil: Sebagian besar responden berusia $>35$ tahun $(85,7 \%)$, Indeks Massa Tubuh (IMT)>20 kg / m2 (76,2\%), jumlah leukosit <10.000/ $\mu \mathrm{L}$ (42,9\%), dan tingkat PCT $\leq 0,5 \mathrm{ng} / \mathrm{mL}$ (61,9\%). Tidak terdapat korelasi yang bermakna antara sel darah putih (WBC) dan PCT dengan uji Korelasi Spearman ( $p=0,061 ; r=0,641)$.

Kesimpulan: Hasil penelitian saat ini menunjukkan bahwa tidak terdapat korelasi yang bermakna antara kadar serum PCT dengan jumlah leukosit pada pasien dengan sepsis.
${ }^{1}$ Mahasiswa Pendidikan Dokter, Fakultas Kedokteran, Universitas Udayana, Bali, Indonesia ${ }^{2}$ Departemen Patologi Klinik, Fakultas Kedokteran, Universitas Udayana, RSUP Sanglah, Bali, Indonesia

\section{"Korespondensi:}

Bagus Dwiki Arya Dharma; Mahasiswa Pendidikan Dokter, Fakultas Kedokteran, Universitas Udayana, Bali, Indonesia; bdwikey@gmail.com

Diterima: 15-06-2019 Disetujui: 11-03-2020 Diterbitkan: 01-04-2020

Kata Kunci: prokalsitonin, jumlah leukosit, sepsis

Cite Pasal Ini: Dharma, B.D.A., Mulyantari, N.K., Prabawa, I.P.Y. 2020. Analisis korelasi kadar serum prokalsitonin dengan jumlah leukosit pada penderita dengan kecurigaan sepsis di RSUP Sanglah, Bali, Indonesia. Intisari Sains Medis 11(1): 179-182. D0l: 10.15562/ism.v11i1.525

\section{PENDAHULUAN}

Sepsis merupakan suatu respon inflamasi sistemik terhadap infeksi, dimana patogen atau toksin dilepaskan ke dalam sirkulasi darah sehingga terjadi aktivasi proses inflamasi. Sepsis ditandai dengan perubahan temperatur tubuh, perubahan jumlah leukosit, tachycardia dan tachypnea. ${ }^{1}$ Gejala klinik sepsis didahului tanda-tanda sepsis non spesifik diantaranya demam, menggigil, dan disorientasi. ${ }^{2}$
Di Amerika Serikat sepsis dilaporkan meningkat dalam 20 tahun terakhir, di perkirakan jumlah kasus sepsis 400.000 - 500.000 setiap tahun. ${ }^{1}$ Data di Amerika Serikat menunjukan pada tahun 1979 tercatat 164.000 kasus sepsis $(82,7 / 100.000$ populasi), sedangkan pada tahun 2000 tercatat 660.000 kasus $(240,4 / 100.000$ populasi) dimana terjadi peningkatan insiden per tahun $8,7 \% .^{3}$ Sedangkan 
data prevalensi di Indonesia mengenai angka kejadian sepsis masih terbatas dilaporkan.

Sepsis merupakan penyebab mortalitas dan morbiditas utama pada pasien yang dirawat di rumah sakit terutama pada pasien dengan usia lanjut, pasien dengan keadaan immunocompromized, dan pasien dengan penyakit kronik. Sepsis juga penyebab utama masuknya pasien ke Intensive care unit (ICU) untuk kasus non kardiologi dan penyebab kedua terbesar kematian di ICU. ${ }^{4}$

Pada temuan laboratorium sepsis awal ditandai oleh leukositosis, trombositopenia, hiperbilirubinemia, dan proteinuria. Trombositopenia memburuk disertai perpanjangan waktu trombin, penurunan fibrinogen, keberadaan D-dimer yang menunjukan Disseminated Intravascular Coagulation (DIC). ${ }^{2}$

Tes laboratorium yang digunakan untuk mengetahui adanya proses-proses inflamasi yaitu protein C-reaktif, laju endap darah, jumlah leukosit, Tumor Necrosis Factor (TNF), Interleukin 1 dan $6 .^{5}$ Akan tetapi pemeriksaan tersebut tidak terlalu spesifik, karena sulit membedakan pasien dengan Systemic inflammatory respon syndrome (SIRS) dan sepsis pada pasien di ruang rawat intensif dalam waktu cepat. Oleh karena itu diperlukan tes yang dapat membedakan antara inflamasi karena infeksi dan inflamasi karena non infeksi.

Telah dikembangkan tes baru untuk mendeteksi inflamasi karena infeksi yaitu prokalsitonin (PCT). Tesinibanyak digunakan untukmembedakan antara SIRS dan sepsis. ${ }^{6}$ Prokalsitonin adalah penanda respon inflamasi dan dirangsang oleh produk bakteri seperti endotoksin/Lipopolisakarida (LPS) dan sitokin (IL-1, IL-2, IL-6, TNF) peran biologis dari PCT sebagian besar masih belum diketahui, namun, data terbaru menunjukkan bahwa PCT memainkan peran patologis pada sepsis. ${ }^{6}$

Berdasarkan penelitian literatur prevalensi sepsis berbeda di setiap Negara di dunia. Sepsis menyebabkan angka mortalitas dan morbiditas yang tinggi, di Rumah Sakit Sanglah Denpasar didapatkan cukup banyak penderita sepsis. Peneliti ingin mengetahui lebih dalam menggunakan pemeriksaan prokalsitonin sebagai tanda spesifik bakteri. Dan juga hal inilah yang membuat peneliti tertarik untuk melakukan penelitian mengenai Korelasi antara Kadar Serum Prokalsitonin dengan Jumlah Leukosit pada Penderita dengan Kecurigaan Sepsis di RSUP Sanglah sehingga dapat diketahui hubungan kadar serum prokalsitonin dengan jumlah leukosit di Rumah Sakit Sanglah Denpasar.

\section{METODE}

Studi ini merupakan penelitian analitik observasional dengan rancangan potong lintang (cross sectional) yang dilakukan pada Laboratorium Patologi Klinik Rumah Sakit Umum Pusat Sanglah selama bulan Februari sampai dengan Juni 2016 terhadap 21 pasien dewasa sepsis. Kriteria inklusi pada studi ini adalah pasien dewasa dengan catatan rekam medis menderita Sepsis di RSUP Sanglah Denpasar antara bulan Februari - Juni 2016, sedangkan kriteria eksklusi adalah pasien sepsis usia di atas 60 tahun maupun dengan penyakit komorbid seperti kanker tiroid, infeksi jamur, indeks masa tubuh kurang dari $18,5 \mathrm{~kg} / \mathrm{m}^{2}$, dan pasien sepsis yang tidak memiliki data prokalsitonin dari rekam medis. Pemilihan subyek penelitian dilakukan dengan memasukan semua subyek yang datang dengan memenuhi kriteria inklusi dan eksklusi sampai jumlah subyek yang diperlukan terpenuhi secara konsekutif (Consecutive sampling).

Setelah didapatkan 21 jumlah sampel pasien dengan sepsis yang diperiksa kadar prokalsitonin kemudian dilakukan data entry dan analisis data menggunakan program SPSS versi 17.0 untuk Windows. Uji pertama yang dilakukan untuk data adalah uji normalitas untuk mengetahui apakah data berdistribusi normal atau tidak. Apabila sampel memiliki distribusi normal $(p>0,05)$ maka dilakukan uji non parametrik korelasi pearson, apabila sampel tidak berdistribusi normal maka dilakukan uji korelasi spearman.

\section{HASIL}

Pasien sepsis dewasa yang berkunjung ke RSUP Sanglah Denpasar pada bulan Februari-Juni 2016 adalah sebanyak 123 orang. Pengambilan data telah dilakukan dengan memperhatikan kriteria inklusi dan eksklusi. Sebanyak 21 dari 123 pasien memenuhi kriteria inklusi dan eksklusi. Pengambilan data ini dilakukan di Ruang Rekam Medis RSUP Sanglah Denpasar.

Dalam Tabel 1 dapat dilihat pasien sepsis lebih rentan pada usia lebih dari 35 tahun dengan jumlah sampel $18(85,7 \%)$, sedangkan pada usia 25 35 tahun sebanyak 3 sampel (14,3\%). Rata-rata usia pasien adalah 44 tahun dengan usia tertua 59 dan usia termuda 25 (Tabel 1).

Berdasarkan Tabel 1, rentang indeks massa tubuh pasien sepsis di RSUP Sanglah adalah 15-33 dengan IMT 15-20 sebanyak 5 sampel $(23,8 \%)$ dan IMT $>20$ sebanyak 16 sampel (76,2\%). Rata-rata indeks massa tubuh pasien sepsis di RSUP Sanglah adalah 23,62 dengan IMT terendah 17 dan IMT terbesar 33. Distribusi IMT pada pasien sepsis dapat dilihat pada Tabel 1.

Berdasarkan Tabel 1, jumlah sampel dengan jumlah leukosit $<10.000$ sebanyak 9 sampel (42,9\%), sampel dengan jumlah leukosit 10.000 20.000 sebanyak 7 sampel (33,3\%), dan sampel 
Tabel 1 Distribusi pasien sepsis berdasarkan karakteristik demografis pasien

\begin{tabular}{lcc}
\hline Variabel & Jumlah (N=21) & Persentase (\%) \\
\hline Usia (Tahun) & & \\
$25-35$ & 3 & 14,3 \\
$\quad 35$ & 18 & 85,7 \\
IMT $(\mathbf{k g} / \mathbf{m} 2)$ & & \\
$\quad 15-20$ & 5 & 23,8 \\
$\quad>20$ & 16 & 76,2 \\
WBC $(\boldsymbol{\mu L})$ & & \\
$\quad<10.000$ & 9 & 42,9 \\
$10.000-20.000$ & 7 & 33,3 \\
$>20.000$ & 5 & 23,8 \\
PCT $(\mathbf{n g} / \mathbf{m l})$ & & \\
$\leq 0,5$ & 13 & 61,9 \\
$>0,5$ & 8 & 38,1 \\
\hline
\end{tabular}

Tabel 2 Uji normalitas dan korelasi kadar serum PCT dengan jumlah leukosit

\begin{tabular}{lccc}
\hline Variabel & Shapiro-Wilk & $\mathbf{P}$ & $\mathbf{r}$ \\
\hline WBC & 0,002 & 0,061 & 0,641 \\
PCT & 0,018 & & \\
\hline
\end{tabular}

dengan jumlah leukosit $>20.000$ sebanyak 5 sampel $(23,8 \%)$. Rata-rata jumlah leukosit pada pasien sepsis di RSUP Sanglah sebesar 14.088,57 dengan jumlah leukosit terendah 4.190 dan tertinggi 34.310. Distribusi jumlah leukosit pada pasien sepsis di RSUP Sanglah dapat dilihat pada Tabel 1.

Berdasarkan Tabel 1, jumlah sampel dengan kadar serum $\mathrm{PCT}<0,5 \mathrm{ng} / \mathrm{ml}$ sebanyak 13 sampel (61,9\%), sampel dengan kadar serum PCT $>0,5 \mathrm{ng} /$ ml sebanyak 8 sampel $(38,1 \%)$. Rata-rata kadar serum PCT pada pasien sepsis di RSUP Sanglah sebesar 7,5 dengan kadar serum PCT terendah $0,11 \mathrm{ng} / \mathrm{ml}$ dan tertinggi $41,55 \mathrm{ng} / \mathrm{ml}$. Distribusi kadar serum PCT pada pasien sepsis di RSUP Sanglah dapat dilihat pada Tabel 1 .

Uji Normalitas dengan menggunakan SaphiroWilk test sebagai syarat uji bivariat spearman. Dapat dilihat pada Tabel 2, uji normalitas didapatkan data tidak terdistribusi normal pada variabel kadar serum PCT dan jumlah leukosit. Oleh karena sampel tidak berdistribusi normal (Nilai $\mathrm{p}<0,05$ ) maka peneliti menggunakan uji Korelasi Spearman.

Hasil analisis bivariat menggunakan Spearman test antara jumlah leukosit dan PCT dapat dilihat pada Tabel 2. Dari hasil analisis menunjukan nilai $\mathrm{p}=0,061$ dan koefisien korelasi (r) sebesar 0,641 menandakan korelasi yang tidak bermakna antara kadar serum PCT dengan jumlah leukosit pada penderita sepsis.

\section{PEMBAHASAN}

Pada penelitian diperoleh 21 sampel penderita sepsis yang di diagnosis di RSUP Sanglah Denpasar pada bulan februari - juni 2016. Berdasarkan distribusi pasien sepsis di RSUP Sanglah lebih dominan pada usia diatas 35 tahun yakni sebanyak 18 sampel (85,7\%) dibandingkan dengan usia 25 - 35 tahun yakni sebanyak 3 sampel (14,3\%). Hasil ini didapat juga oleh Octavia S pada tahun 2015 yang menunjukkan distribusi sepsis lebih banyak pada usia diatas 35 tahun. $^{7}$

Pada penelitian ini diperoleh sampel terbanyak pada jumlah leukosit dibawah $10.000 / \mu \mathrm{L}$ yaitu 9 sampel (42,9\%). Terdapat perbedaan pada penelitian yang dilakukan oleh Octavia S, jumlah leukosit yang didapat mengalami peningkatan diatas 11.000/ $\mu \mathrm{L}^{7}$ Adanya ketidaksesuaian ini dapat disebabkan faktor komorbiditas dan kesalahan melakukan pemeriksaan laboratorium pada waktu jumlah leukosit dalam darah belum meningkat. Jumlah leukosit umumnya mengalami peningkatan pada proses infeksi yang biasanya didominasi oleh sel-sel neutrophil,yang mana neutrophil tersebut merupakan barisan terdepan dari sistem pertahanan.

Distribusi kadar serum prokalsitonin (PCT) pada pasien sepsis didapatkan sampel terbanyak dengan kadar serum PCT kurang dari 0,5 ng/ml sebanyak 13 sampel (61,9\%), sampel dengan kadar serum PCT lebih dari $0,5 \mathrm{ng} / \mathrm{ml}$ sebanyak 8 sampel $(38,1 \%)$. Pada penelitian Octavia S, sampel terbanyak terdapat pada kadar serum PCT dibawah $0,25 \mathrm{ng} / \mathrm{ml}$ yaitu 20 sampel (46,5\%), kadar serum PCT 0,25-0,49 ng/ml sebanyak 13 sampel (30,2\%), dan kadar serum PCT diatas $0,50 \mathrm{ng} / \mathrm{ml}$ sebanyak 10 sampel $(23,3 \%) .^{7}$ Dimana terdapat perbedaan angka titik potong atau cut of point yang di teliti. PCT diinduksi oleh endotoksin yang dihasilkan bakteri selama infeksi sistemik. Infeksi yang disebabkan protozoa, infeksi non-bakteri (virus) dan penyakit autoimun tidak menginduksi $\mathrm{PCT} .{ }^{8} \mathrm{Kadar}$ serum PCT muncul cepat dalam dua jam setelah rangsangan, puncaknya setelah 12 sampai 48 jam dan secara perlahan menurun dalam 48 sampai 72 jam. PCT dinyatakan sebagai "gold standard" sebagai marker pada pasien sepsis, dengan nilai sensitivitas dan spesifitas diatas $80 \%$ dibandingkan dengan marker lain seperti CRP, TNF- $\alpha$, atau IL-2. ${ }^{8}$

Dari hasil analisis menunjukan nilai $\mathrm{p}$ sebesar 0,061 dan koefisien korelasi (r) sebesar 0,641 menandakan korelasi yang tidak signifikan antara kadar serum PCT dengan jumlah leukosit pada penderita sepsis, Pada penelitian Murzalina C tahun 2007 menyatakan korelasi antara kadar serum PCT dan jumlah leukosit yaitu $\mathrm{p}<0.05$ $(\mathrm{p}=0.034)$ dengan $\mathrm{r}=0.558$ yang berarti adanya korelasi bermakna antara kadar serum PCT 
dengan jumlah leukosit. ${ }^{9}$ Hal tersebut tidak selaras dengan penelitian Octavia $S$ yang menyatakan tidak ada hubungan yang bermakna pada PCT dengan jumlah leukosit, didapatkan nilai $\mathrm{r}=0.129$ dan $p>0.05(0.411) .^{7}$ Dimana terdapat perbedaan pada karakteristik sampel yang diteliti yaitu jenis kelamin, riwayat penyakit terdahulu, dan tanda vital. $^{7}$ Ketidaksesuaian pada penelitian ini juga dapat disebabkan oleh kesalahan pengambilan spesimen darah atau pemeriksaan laboratorium., ${ }^{9,10}$ Oleh karena kadar PCT terdapat hubungan dengan jumlah leukosit, maka pemeriksaan jumlah leukosit dapat dipakai sebagai marker pada pasien sepsis. Dengan demikian meningkatnya kadar serum PCT, jumlah leukosit ikut meningkat.

\section{SIMPULAN}

Terdapat korelasi yang tidak signifikan antara kadar serum PCT dengan jumlah leukosit pada pasien sepsis di RSUP Sanglah Denpasar. Kadar serum PCT pada penderita sepsis ditemukan meningkat dengan nilai $>0,05 \mathrm{ng} / \mathrm{ml}$. Sedangkan jumlah leukosit pada penderita sepsis ditemukan meningkat dengan nilai $>10.000 \mu \mathrm{L}$. Oleh karena itu perlu dilakukan penelitian lebih lanjut dengan jumlah sampel yang lebih besar ke depannya dalam memperoleh hasil yang representatif.

\section{KONFLIK KEPENTINGAN}

Tidak terdapat konflik kepentingan dalam penulisan laporan penelitian ini

\section{ETIKA PENELITIAN}

Penelitian ini telah mendapatkan persetujuan etik dari Komisi Etik, Fakultas Kedokteran Universitas Udayana, Bali, Indonesia sebelum penelitian berjalan.

\section{PENDANAAN}

Penulis bertanggung jawab dalam pendanaan penelitian ini tanpa melibatkan pihak sponsor, beasiswa, ataupun sumber pendanaan lainnya.

\section{KONTRIBUSI PENULIS}

Seluruh penulis bertanggung jawab dalam penulisan laporan penelitian ini baik dari pembuatan kerangka konsep, pengumpulan sampel penelitian, tabulasi data, analisis data penelitian, hingga melaporkan hasil penelitian.

\section{DAFTAR PUSTAKA}

1. Assicot M, Gendrel D, Carsin H, Raymond J, Guilbaud J, Bohuon C. High serum procalcitonin concentrations in patients with sepsis and infection. Lancet. 1993 Feb 27;341(8844):515-8.

2. Herzum I, Renz H. Inflammatory markers in SIRS, sepsis and septic shock. Curr Med Chem. 2008;15(6):581-7.

3. Dellinger RP, Levy MM, Rhodes A, Annane D, Gerlach H, Opal SM, et al. Surviving sepsis campaign: international guidelines for management of severe sepsis and septic shock: 2012. Crit Care Med. 2013;41(2):580-637.

4. Berger MM, Marazzi A, Freeman J, Chioléro R. Evaluation of the consistency of Acute Physiology and Chronic Health Evaluation (APACHE II) scoring in a surgical intensive care unit. Crit Care Med. 1992;20(12):1681-7

5. Zhang JM, An J. Cytokines, Inflammation and Pain. Int Anesthesiol Clin. 2007;45(2): 27-37.

6. Becker KL, Snider R, Nylen ES. Procalcitonin assay in systemic inflammation, infection, and sepsis: clinical utility and limitations. Crit Care Med. 2008 Mar;36(3):941-52.

7. Octavia S. Hubungan antara Leukosit dengan Prokalsitonin sebagai Biomarker Sepsis di Rumah Sakit Umum Pusat Haji Adam Malik Bulan Agustus - Oktober 2015 Medan [Skripsi]. Fakultas Kedokteran Universitas Sumatera Utara. 2015

8. Uzzan B, Cohen R, Nicolas P, Cucherat M, Perret GY. Procalcitonin as a diagnostic test for sepsis in critically ill adults and after surgery or trauma: A systematic review and meta-analysis. Crit Care Med. 2006;34(7):1996-2003.

9. Murzalina C. Procalcitonin Pada Pasien Sepsis Yang Telah Mendapat Perawatan Di Ruang Rawat Intensif [Tesis]. Departemen Patologi Klinik Fakultas Kedokteran Universitas Sumatera Utara. 2007

10. Magrini L, Gagliano G, Travaglino F, Vetrone F, Marino R, Cardelli P. Comparison between white blood cell count, procalcitonin and $\mathrm{C}$ reactive protein as diagnostic and prognostic biomarkers of infection or sepsis in patients presenting to emergency department. Clin Chem Lab Med. 2014;52(10):1465-72.

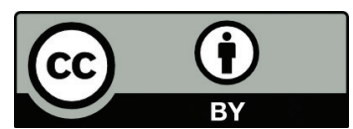

This work is licensed under a Creative Commons Attribution 